\title{
Relational Dimensions of Regional Growth: Introduction to the Special Issue
}

\author{
Pere Suau-Sanchez, Montserrat Pallares-Barbera, Christine Tamásy, Mike Taylor \\ Pere Suau-Sanchez, Department of Air Transport, Cranfield University, UK \\ (p.suausanchez@cranfield.ac.uk) \\ Montserrat Pallares-Barbera, Department of Geography, Universitat Autònoma de Barcelona, Spain \\ (montserrat.pallares@uab.cat) \\ Christine Tamásy \\ Institute for Spatial Analysis and Planning, University of Vechta, Germany (ctamasy@ispa.uni-vechta.de) \\ Mike Taylor, School of Geography, Earth and Environmental Sciences, University of Birmingham, UK \\ (m.j.taylor@bham.ac.uk)
}

\section{Introduction}

The study of the distribution of economic activities across space has always been the essence of economic geography, regional economics, and related disciplines. Empirical analyses have provided significant evidence, for example, that especially urbanized regions are very successful in developing innovation and employment (e.g., Wedemeier 2009). A prerequisite for the generation of economic growth is, however, the capability of economic agents to be creative and to develop new ideas. A relational perspective places the analytical focus on the complex nexus of economic relations between actors and structures. It has been argued that changes in the relations between actors and structures foster dynamic transformations in the spatial organization of economic activities (Boggs and Rantisi 2003). Hence, relational economic growth is concerned with the ways in which socio-spatial relations of actors are interlaced with structures and processes of economic change at various geographical scales (Yeung, 2005). Bathelt and Glückler (2003) argued that the relational perspective has three fundamental components: (a) economic actors operate within frameworks of social and institutional relations; (b) economic processes are path-dependent, with future actions constrained to some extent by past decisions; and (c) economic processes can also shaped by agents' free will, unconstrained by existing development paths. According to Jones (2009, p. 487) recent years "have witnessed a burgeoning of work on 'thinking space relationally'”, even though there seem exists some silence on factors that, for example, constrain, structure, and connect space (see also Sunley 2008).

This issue, Relational Dimensions of Regional Growth, aims to advance relational thinking by providing new and further in-depth theoretical insights and empirical perspectives in this field. The papers reflect on the central issues of knowledge, networks and work. They were first presented at the 2008 meeting of the International Geographical Union (IGU) Commission on the Dynamics of Economic Spaces held in Barcelona from the $5^{\text {th }}$ to the $8^{\text {th }}$ of August. The main topics of the meeting were the multi-scalar dynamics of new economic spaces; and this issue draws 
together the papers from that meeting that explore regional economic growth and its relational facets.

\section{Relational economic geography}

In the past decade, relational economic geography has developed significantly, using Granovetter's (1985) concept of "embeddedness" to understand and explain the dynamics of local economies in terms of social-spatial interactions between firms, institutions, and other economic actors (Yeung, 2005). These relationships are built on four pillars; organization, interaction, innovation and evolution (Bathelt and Gluckler, 2003). They are interpreted as being path-dependent and involving open-ended strategies that, in turn, tie institutions and enterprises into functional economic networks.

Built on the concept of embeddedness, relational thinking in economic geography has become an influential model of local economic growth that draws on a range of complementary literatures on "clusters", "new industrial spaces", "learning regions", "innovative milieu" and "regional innovation systems" (see for example, MacKinnon, et al., 2002; Braczyk, et al., 1998; Storper, 1997), sometimes referred to as "new regionalism". Research in this field sees economic growth linked not only to market conditions, but also to repeated inter-firm interaction and knowledge exchange, collaborative long-term buyer-supplier relationships, the creation of social capital (including trust, reciprocity and loyalty), and a supportive tissue of local institutional thickness, than to market conditions (see Malmberg and Maskell, 2006; Cumbers, et al., 2003). As such, relational thinking within geography stands in strong opposition to the "new economic geograhy" in economics (see, for example, the work of Krugman, 1991). Indeed, relational thinking in economic geography has brought a renewed interest in the advantages of geographical proximity between firms in related industries (Keeble and Nachum, 2002).

The papers in this issue continue this developing debate and discussion of relational ideas in economic geography, and bring new thinking and new empirical material to test, challenge and clarify this emerging theoretical perspective.

The papers in the first part of this issue focus on cluster development as a source of regional growth. In the first paper, Jeong Lee and Hyungjoo Kim analyze the path evolution of three Korean clusters. They use a multi-scalar approach avoiding treating each scale level as a separate and independent factor. They argue that exogenous factors and government policies should be incorporated as major reasons for differentiated cluster development, in addition to the differential working of local business networks and other endogenous elements. In the second paper, Sang-Chul Park also reflects on Korean cluster development. While Lee and Kim emphasized the macro level in their analysis, Park focuses on regional and local levels, while also recognizing the importance of government policies on innovation and cluster growth. The paper focuses on the transformation of national industrial complexes into innovative clusters, a concept that emphasises the interaction between firms, government and educational institutions. In the third paper, by Júlia Bosch, Laura Capel, François Cougoule, Gissel Ferrari and Sergi Solanas, continue the focus on technological and innovative clusters. These researchers explore the competition aspects of 23 world clusters, using the “22@Barcelona” cluster as a detailed case study. While the first three papers of this issue have explored principally metropolitan clusters, in the fourth paper of the issue Linda Lundmark and Örjan Pettersson explore the importance of clusters in rural areas. 
Lundmark and Pettersson show that principles and processes underpinning innovative clusters in metropolitan areas cannot always be used as a blue print for economic development in rural and sparsely populated areas of a country. They explore this issue in the Swedish context where, because of the country's particular geography, regional policy for non-metropolitan areas requires thoughtful consideration. In combination, the first four papers of this issue demonstrate the important role that governments and institutions play the shaping of successful clusters. Paper five extends this understanding by focusing on the relations among actors within economic clusters. Building on communication and cognitive psychology, Michael C. Carroll and Mark C. Zeller explore how the human ability to process information can limit network formation. Recognizing and accommodating this constraint is, therefore, vital to the formulation of successful cluster policies.

The second part of this issue deals with role of knowledge in local economic development. In the sixth paper, Mercedes Rodriguez and José A. Comacho explore the distribution of knowledge intensive services (KIS) throughout Europe. These services are located in main capital regions and regions adjacent to them. Deepening this perspective, the seventh paper by Britta Klagge and Carsten Peter explores the reasons why private equity providers have become increasingly centralized in national financial centres to the detriment of regional centres. Klagge and Peter point out that changes in knowledge management create new patterns of business in the geographical organization of financial actors. In the eighth paper, the focus of investigation is shifted the role of social networks in shaping local economic development. Using social network analysis (SNA), Neil Reid and Bruce W. Smith measure the level of collaboration among local economic development players in the Toledo, $\mathrm{OH}$, metropolitan statistical area. Their analysis leads to the conclusion that social interaction through networks is an important way of obtaining knowledge for local economic development. Extending this perspective, paper nine, by Eike W. Schamp, analyzes the cumulative and path-creating processes that have underlain the transformation and reinvention of a major German footwear producing district into a new technology-based centre. As in the case of Toledo, the development and reinvention of the footwear industry was possible only through the co-ordinated action of a range of economic actors.

The third set of papers in this issue, focuses on the worker and work place dimensions of local and regional economic growth. In the tenth paper, Antònia Casellas, Esteve Dot-Jutgla and Montserrat Pallares-Barbera explore the transformation of an old industrial district in Barcelona into a renovated technological neighbourhood. They use the example of an old industrial factory building that was transformed through the activities and actions of new types of worker, for example artists in collaboration with public institutions. In paper eleven, Carol Ekinsmyth extends this perspective workers and work through an analysis of women moving into self-employment. Ekinsmyth reflects on the importance in this context of social networks in contrast to formal channels for job creation, recruitment and knowledge generation. In paper twelve, Brita Hermelin and Kristina Trygg shift this perspective to the geography of work. Using a case study from Stockholm, they look at knowledge-intensive work in a public sector organization and, for example, where work is done. Their results show how institutional restrictions and self-reflective choices determine the organization of work in time and space. 
The final section of this issue takes an evolutionary approach to relational economic geography. Paper thirteen, by André Scharmanski and Martina Fuchs explores the rationality and routines in the decision-making processes of property investors. They contrast the rationality of choice by firms investing in emerging markets with the experience-based knowledge of traditional property investors that self-replicate through routines. New investors combine both approaches and the resulting decisionmaking behaviour is a combination of rational and path-dependent decisions.

\section{Conclusion}

The papers in this issue demonstrate the breadth, depth and complexity of the issues that underpin the path dependent development of economic regions. They demonstrate the need for sensitive, multifaceted analysis that manifest empirically that the economic development of regions depends not only on maximizing economic benefits through purely rational decision-making, but also, and especially, on the particular routines, networks of involved actors, and different institutional actions that are driven by social, societal and political processes within localities regions and nations. The contributions in this issue also demonstrate the diversity of methodologies required by this relational economic geography perspective, ranging from quantitative models and network analyses to qualitative interviews.

\section{Acknowledgements}

We are very grateful to the international reviewers who refereed individual papers. The refereeing process consisted of two parts: an assessment by a referee selected from the conference participants and an international referee. The reviewing process was anonymous. In addition, we would like to thank Maria Wegehöft, Silke Thöle, Thomas Conradi and Kathrin Wolken for the administrative support.

\section{References}

Bathelt, H. and Glückler, J. (2003), 'Towards a Relational Economic Geography', Journal of Economic Geography, 3, 117-144.

Boggs, J.S. and Rantisi, N.M. 2003. The 'relational turn' in economic geography. Journal of Economic Geography, 3(2), 109-116.

Braczyk, H.J., Cooke, P. and Heidenreich, M. (eds) (1998), Regional Innovation Systems: The Role of Governances in a Globalized World, UCL Press, London.

Cumbers, A., MacKinnon, D. and Chapman, K. (2003), 'Innovation, Collaboration and Learning in Clusters: A Study of SMEs in the Aberdeen Oil Complex', Environment and Planning A, 35, 1689-1706.

Granovetter, M. (1985), 'Economic Action and Social Structure: The Problem of Embeddness', American Journal of Sociology, 91, 481-510.

Jones, M. 2009. Phase space: Geography, relational thinking, and beyond. Progress in Human Geography, 33 (4), 487-506.

Keeble, D.E. and Nachum, L. (2002), 'Why do Business Service Firms Cluster?', Transactions of the Institute of British Geographers, 27 (1), 67-90.

Krugman, P. (1991), Geography and Trade, MIT Press, Cambridge.

MacKinnon, D., A. Cumbers and K. Chapman (2002), 'Learning, Innovation and Regional Development: A Critical Appraisal of Recent Debates', Progress in Human Geography, 26, 293-311.

Malmberg, A. and Maskell, P. (2006), 'Localized Learning Revisited', Growth and 
Change, 37 (1), 1-18.

Storper, M. (1997), The Regional World: Territorial Development in a Global Economy, Guilford Press, New York.

Sunley, P. 2008. Relational economic geography: A partial understanding or a new paradigm? Economic Geography, 84 (1), 1-26.

Wedemeier, J. 2009. The impact of the creative sector on growth in German regions. European Planning Studies, 18 (4), 505-520.

Yeung, H.W. 2005. Rethinking relational economic geography. Transactions of the Institute of British Geographers, 30(1), 37-51. 